\title{
Analysis of distribution of mobile genetic elements within the human TP53 gene and its 5 -flanking region
}

\author{
O. V. Pidpala, A. P. Iatsyshyna, L. L. Lukash \\ The Institute of Molecular Biology and Genetics, NAS of Ukraine \\ 150 Acad. Zabolotny Str., Kyiv, 03143, Ukraine \\ E. mail: specrada@imbg.org.ua
}

\begin{abstract}
Computational analysis of distribution of mobile genetic elements within the human TP53 gene and its 5 -flanking region has been performed. There was no difference revealed for SINE and LINE repeats, but it has been shown that the LINE elements are preferentially present within the TP53 gene and the LINE2 elements are preferentially distributed within 5 -flanking region of the TP53 gene. Alu repeats have been found to be the most common repeats within the TP53 gene and its 5 -flanking region. LTR repeats have been absent at all and DNA transposons have been determined only within the TP53 gene. It has been revealed that mobile genetic elements within TP53 gene and its 5 -flanking region preferentially form clusters, which contain mobile genetic elements from different repeat families and subfamilies.
\end{abstract}

Key words: human TP53 gene, mobile genetic elements, Alu-repeats, mosaic cluster structures.

Introduction According to the peculiarities of structure and the mode of moving, mobile genetic elements (MGE) can be divided into 4 basic classes: SINE (short interspersed nuclear elements), LINE (long interspersed nuclear elements), LTR elements (retrovirus-like elements with long terminal repeats) and DNA-transposons [1]. MGE are not only the factors of spontaneous and inducted mutations [2-4], but they are vAluable functional genome components [5-8]. Due to MGE, genome is considered to be a dynamic system which reacts in an active way to the environment changes [9-12]. Having the promoters of their own, they can change the activity of the gene adjacent to them, form promoters of vitally important genes $[14,15]$ or play the role of various regulatory sequences [16-18].

(C) O. V. PIDPALA, A. P. IATSYSHYNA, L. L. LUKASH, 2006
In human genome the MGE part is app. $45 \%$ of nuclear DNA. They are spread randomly, mainly in intergenic or intron regions, rarely in exons $[6,19]$. In many genes, MGE or sequences, originated from them, are present in promoter, 5'- and 3'- flanking regions, which points out to their important role in functioning of genome, in gene activity regulation, in particular [15, 20].

The human TP53 gene is the oncosuppressor, the mutations of which are the most widely spread disorders in all kinds of malignant tumors [21, 22]. Its basic function is cell genetic stability maintenance and it also participates in apoptosis, reparation, and angiogenesis [23-25]. This polyfunctionality demands complex regulation which possibly involves MGE. Some researches show the presence of SINE class representatives (Alu-repeats) in this gene [26] and in $3 r$-flanking region, in particular, [27] however it is not determined what subfamilies they belong 
to, and other MGE are not mentioned as well. The given data on MGE distribution in TP53 gene in GenBank database (reg. No. AY838896) do not give information about the MGE class and subfamily, detailed analysis of the total amount of MGE in gene in general and in exons and in intorns separately is also absent. Therefore, the aim of our work was to analyze MGE distribution in the human TP53 gene and its 5'-flanking region in details.

Materials and Methods. Human gene TP53 nucleotide sequence was obtained from GenBank (reg. No.U94788, 843 - 20303bp). $5 r$-flanking sequence of this gene (10kb) was obtained from GENE DATABASE GENATLAS web-site (http://www.dsi.univ-paris5.fr/genatlas /struc_exon/TP53_1.html). Both sequences were analyzed for the presence of repeats using RepeatMasker software, available at BCM Search Launcher (http://searchlauncher.bcm.tcm.edu /seq-util.html).

Results and Discussion. Table 1 represents the results of the MGE distribution analysis in the human gene TP53. Summarized data on TP53 gene and its $5 r$-flanking region are represented in Table 2. It has been determined that general percentage of SINE and LINE elements in gene and in its $5 r$-flanking region do not differ essentially. However, LINE1 elements are located in within gene exceptionally, while LINE2 elements are located in 5r-flanking region preferentially. Among MGE Alu-repeats are observed the most frequently. LTR elements are not detected at all, and DNA-transposons in some minor quantity are represented in gene only.

MGE distribution in introns and exons was analyzed (Fig.1). MGE were found in five out of ten human TP53 gene introns. The highest percentage of MGE is in introns 1,6 , and 9 (73.03, 68.96, and $85.45 \%$ respectively). The percentage is lower in introns 4 and 10 (40.66 and 32.83 $\%)$. Two SINE class MGE, namely one MIR element and one Alu-repeat, are present in exon 11. It is worth mentioning that within TP53 gene only Alu-repeats out of 39 MGE sequences are full-sized elements, all the rest are represented in fragments.

Alu-repeats are known to form clusters [28-30], which according to [31, 32] may consist of different subfamilies. The exception is young ALU-repeats subfamilies that are mostly distant from clusters [33]. The involving of Alu-repeats into chromosome reconstruction is discussed [34].

Within TP53 gene there are three big Alu-repeats clusters: two in intron 1 and one in intron 9. One cluster, which is located in intron 1, consists of eleven Alu-repeats and one Alu-monomer (two of which belong to young subfamilies). It is of interest that Alu-repeats in this cluster are surrounded or border with fragments of L1 element, developing composite structures (Fig. 2). The second intron 1 cluster consists of five Alu-repeats. There are cases when one Alu-repeat is inserted into another one (Fig. 2). Alu-repeats that belong to intron 9, form one big cluster, which consists of seven Alu-repeats and one Alu-monomer. In this case the cluster is surrounded with MER2 sequences and one more MER2 sequence is located within this cluster. Analyzing $10 \mathrm{~kb}$ of 5'-flanking region, within which there is WDR79 gene (previously FLJ10385), which codes hypothetical protein LOC55135 and has opposite transcription direction, we revealed that overwhelming majority of Alu-repeats is located in three clusters, the specific feature of which is framing with L2 sequences. Therefore, MGE within both human TP53 gene and its 5'-flanking region mainly (80\% and $73 \%$ ) form mosaic cluster structures, which are contain MGE of different families and subfamilies (among them young Alu-repeats subfamilies are also represented).

As the majority of human TP53 gene mutations are the missence-mutations that take place in exons 5-8 [35] one can discuss MGE involving in mutational processes only in some cases [36-37]. However, regarding large MGE representation in the human TP53 gene $(59.96 \%)$, the question about the role, which they play in genome functioning, arises.

V. A. Ratner defined a special role of MGE as 'movable cassettes of regulatory elements' and later as 'movable cassettes of functional sites' that having various sites of external signals reception, may influence genes expression substantially $[38,7]$. As for Alu-repeats, the presence of functional binding sites for retinoid acid receptors was found [39] in consensus sequence, and additional presence of hormone-acceptor elements was shown for Alu-repeats located in promoter regions of some genes [40].

There are known cases of MGE participation in the regulation of cellular genes expressions [17]. Alu-repeats can be enhancers (e.g. in the case of adenosidiamenase gene) [41], transcriptional modulators (c-myc gene) [42], or transcriptional silencers (PCNA gene) in particular [43]. Alu-repeats can inactivate or change the functions of gene products, creating alternative sites of splicing or interfere into its mechanism (e.g. in the case of subunit of B $1 \mathrm{C}-2$ integrin) [44]. They can also act as insulators (KRT 18 gene) [45] and evidently implement other functions[46-48]. The presence of Alu-repeats and other retroposons in pre-mRNA affect polyadenilation of transcripts as well as influence translation effectiveness [49-51]. Alu-repeats contribute to the methylation of neighboring loci providing one more mechanism of control over genes expression [52-53].

High abundance of MGE in the analyzed human TP53 gene and its 5'-flanking region is probably connected with 
Table 1.

Distribution Analysis of mobile genetic elements and their fragments in human TP53 gene.

\begin{tabular}{|c|c|c|c|c|c|}
\hline MGE & Class/family & $\begin{array}{l}\text { Coordinates in gene } \\
\text { borders }\end{array}$ & Length(b.p.) & Chain & Localization \\
\hline L1M2 & LINE/L1 & $1516-1749$ & 234 & + & Intron 1 \\
\hline AluSq & SINE/Alu & $1750-2043$ & 294 & - & Intron 1 \\
\hline L1ME2 & LINE/L1 & 2044-3031 & 988 & + & Intron 1 \\
\hline AluJo & SINE/Alu & $3082-3379$ & 298 & + & Intron 1 \\
\hline L1 & LINE/L1 & $3426-3485$ & 60 & - & Intron 1 \\
\hline AluSx & SINE/Alu & $3486-3787$ & 302 & - & Intron 1 \\
\hline $\mathrm{L} 1$ & LINE/L1 & $3787-3959$ & 172 & - & Intron 1 \\
\hline AluSx & SINE/Alu & $3960-4095$ & 136 & - & Intron 1 \\
\hline AluSq & SINE/Alu & $4096-4385$ & 290 & - & Intron 1 \\
\hline AluSx & SINE/Alu & $4386-4560$ & 175 & - & Intron 1 \\
\hline L1 & LINE/L1 & $4561-4618$ & 58 & - & Intron 1 \\
\hline FLAM_c & SINE/Alu & $4621-4737$ & 117 & - & Intron 1 \\
\hline L1 & LINE/L1 & $4749-4974$ & 226 & - & Intron 1 \\
\hline AluY & SINE/Alu & $4975-5288$ & 314 & - & Intron 1 \\
\hline L1 & LINE/L1 & $5289-5395$ & 107 & - & Intron 1 \\
\hline AluY & SINE/Alu & $5396-5701$ & 306 & - & Intron 1 \\
\hline AluSq & SINE/Alu & $5710-5851$ & 142 & - & Intron 1 \\
\hline AluSq & SINE/Alu & $5852-6147$ & 296 & - & Intron 1 \\
\hline AluSq & SINE/Alu & $6148-6327$ & 180 & - & Intron 1 \\
\hline $\mathrm{L} 1$ & LINE/L1 & $6328-6401$ & 74 & - & Intron 1 \\
\hline AluSq & SINE/Alu & $6402-6664$ & 263 & - & Intron 1 \\
\hline AluSx & SINE/Alu & $6665-6984$ & 320 & - & Intron 1 \\
\hline $\mathrm{L} 1$ & LINE/L1 & $6992-7052$ & 387 & - & Intron 1 \\
\hline MER2 & DNA/MER2 & $7062-7281$ & 220 & - & Intron 1 \\
\hline MIR & SINE/MIR & $7776-7853$ & 58 & + & Intron 1 \\
\hline AluSq & SINE/Alu & $7861-8192$ & 332 & - & Intron 1 \\
\hline AluSp & SINE/Alu & $8257-8557$ & 301 & - & Intron 1 \\
\hline AluJo & SINE/Alu & $8668-8719$ & 52 & - & Intron 1 \\
\hline AluSx & SINE/Alu & $8720-9036$ & 317 & - & Intron 1 \\
\hline AluJo & SINE/Alu & $9037-9202$ & 166 & - & Intron 1 \\
\hline AluSq & SINE/Alu & $9210-9520$ & 311 & - & Intron 1 \\
\hline $\mathrm{L} 2$ & LINE/L2 & $9666-9863$ & 198 & + & Intron 1 \\
\hline AluSx & SINE/Alu & $10235-10530$ & 296 & - & Intron 1 \\
\hline $\mathrm{L} 2$ & LINE/L2 & $10532-10710$ & 179 & + & Intron 1 \\
\hline
\end{tabular}




\begin{tabular}{ll|c|c|c|c}
\hline \multicolumn{1}{c}{ MGE } & \multicolumn{1}{c}{ Class/family } & $\begin{array}{c}\text { Coordinates in gene } \\
\text { borders }\end{array}$ & Length(b.p.) & Chain & Localization \\
\hline AluJb & SINE/Alu & $11754-12060$ & 307 & - & Intron 4 \\
MIR & SINE/Alu & $12683-12774$ & 92 & + & Intron 6 \\
AluY & SINE/Alu & $12789-13087$ & 299 & - & Intron 6 \\
MER47A & DNA/MER2 & $14178-14307$ & 130 & + & Intron 9 \\
AluSq & SINE/Alu & $14308-14624$ & 317 & + & Intron 9 \\
AluJo & SINE/Alu & $14637-14854$ & 218 & + & Intron 9 \\
AluJb & SINE/Alu & $14863-15028$ & 166 & + & Intron 9 \\
AluSg & SINE/Alu & $15033-15343$ & 311 & + & Intron 9 \\
AluJo & SINE/Alu & $15346-15637$ & 292 & + & Intron 9 \\
MER47A & DNA/MER2 & $15638-15792$ & 155 & - & Intron 9 \\
AluSx & SINE/Alu & $15855-16151$ & 297 & - & Intron 9 \\
FLAM_A & SINE/Alu & $16155-16279$ & 125 & - & Intron 9 \\
AluSx & SINE/Alu & $16281-16571$ & 291 & + & Intron 9 \\
MER47A & DNA/MER2 & $16587-16692$ & 106 & - & Intron 10 \\
AluSp & SINE/Alu & $17250-17551$ & 302 & - & Exon 11 \\
MIR & SINE/MIR & $18206-18308$ & 102 & + & Exon 11 \\
AluJb & SINE/Alu & $18601-18900$ & 300 & & +
\end{tabular}

Table 2.

Mobile genetic elements in human TP53 gene and its 5'-flanking region

\begin{tabular}{|c|c|c|c|c|c|c|}
\hline \multirow[b]{2}{*}{$\begin{array}{l}\text { Type of the } \\
\text { element }\end{array}$} & \multicolumn{3}{|c|}{ Human TP53 gene } & \multicolumn{3}{|c|}{ 5?- flanking region $(10 \mathrm{~kb})$} \\
\hline & $\begin{array}{l}\text { Quantity of the } \\
\text { elements in the } \\
\text { analyzed region }\end{array}$ & $\begin{array}{l}\text { The length of the } \\
\text { nucleotide } \\
\text { sequence, which } \\
\text { is occupied by the } \\
\text { current type } \\
\text { elements (b.p.) }\end{array}$ & $\begin{array}{l}\text { Percentage of } \\
\text { total length of the } \\
\text { analyzed region } \\
(\%)\end{array}$ & $\begin{array}{l}\text { Quantity of the } \\
\text { elements in the } \\
\text { analyzed area }\end{array}$ & $\begin{array}{l}\text { The length of the } \\
\text { nucleotide } \\
\text { sequence, which } \\
\text { is occupied by the } \\
\text { current type } \\
\text { elements, (b.p.) }\end{array}$ & $\begin{array}{l}\text { Percentage of } \\
\text { total length of the } \\
\text { analyzed region, } \\
(\%)\end{array}$ \\
\hline SINE: & 33 & 8686 & 44,63 & 18 & 4719 & 47,19 \\
\hline Alu & 30 & 8433 & 43,33 & 17 & 4575 & 45,75 \\
\hline MIR & 3 & 253 & 1,30 & 1 & 144 & 1,44 \\
\hline LINE: & 4 & 2372 & 12,19 & 6 & 1825 & 18,25 \\
\hline LINE 1 & 2 & 1995 & 10,25 & 0 & 0 & 0 \\
\hline LINE 2 & 2 & 377 & 1,94 & 6 & 1825 & 18,25 \\
\hline L3/CR 1 & 0 & 0 & 0 & 0 & 0 & 0 \\
\hline LTR elements & 0 & 0 & 0 & 0 & 0 & 0 \\
\hline $\begin{array}{l}\text { ДНК-transpos } \\
\text { ons: }\end{array}$ & 2 & 611 & 3,14 & 0 & 0 & 0 \\
\hline MER 1 & 0 & 0 & 0 & 0 & 0 & 0 \\
\hline MER 2 & 2 & 611 & 3,14 & 0 & 0 & 0 \\
\hline Total & 39 & 11669 & 59,96 & 24 & 6544 & 65,44 \\
\hline
\end{tabular}




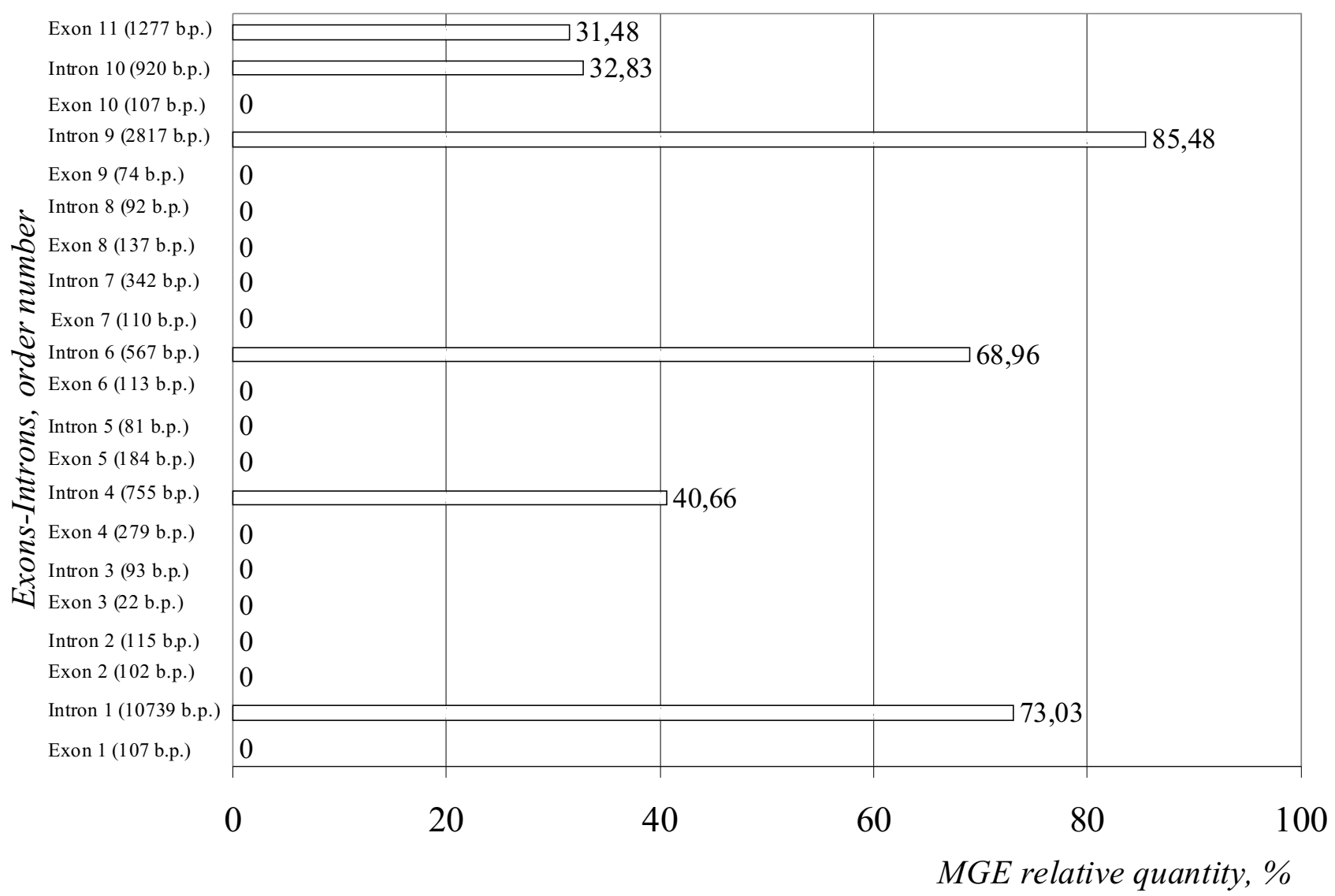

Figure 1. The distribution of MGE in human TP53 gene

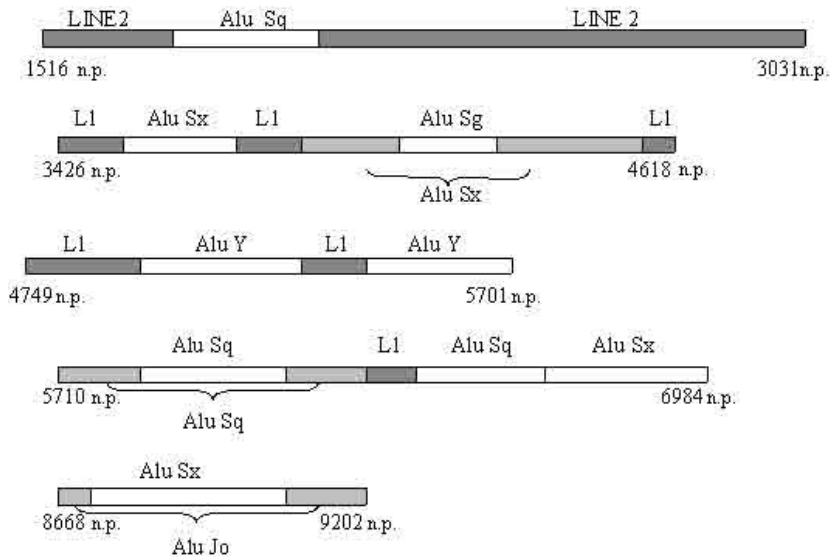

Fig 2. Compositional structures of different families/subfamilies of MGE within clusters of Intron 1 of human TP53 gene (numbers are the coordinates within present gene) their participation in the regulation of this gene. Therefore, in our further researches we plan on more detailed analysis of the representatives of Alu-repeats subfamily to determine various functional sites in order to define the MGE role, Alu-repeats in particular, in the expression of the human TP53 gene.

Acknowledgements.. We express sincere gratitude to S.M. Kvasha, PhD. (biology), for methodological and consulting help.

\section{О. В. Пидпала, А. П. Ячышина, Л. Л. Лукаш}

Анализ распределения мобильных генетических элементов в гене ТР53 человека и его 5' -фланкирующем участке

Резюме

Проведен компьютерный анализ распространения мобильных генетических элементов (МГЭ) в генетте Т९53 человека и его 5' -фланкирующем участке. Не выявлено существенной разницы для SINE- 
u LINE-элементов, однако показано, что LINE1-элементы присутствуют исключительно в гене, тогда как LINE2 ? преимущественно в 5'-фланкирующем участке. Среди МГЭ чаще всего встречаются Alи-повторы. Совсем не обнаружено LTR-элементов, а ДНК-транспозоны в незначительном количестве представлены лишь в гене. Как в гена, так и его 5'-фланкирующем участке МГЭ преимущественно формируют кластерные мозаичные структуры, в состав которых входят элементы разных семейств и подсемейств.

Ключевые слова: ген ТР5Зчеловека, мобильные генетические элементы, Alи-повторы, кластерные мозаичные структуры.

\section{REFERENCES}

1. International Human Genome Sequencing Consortium: Initial sequencing and analysis of the human genome// Nature. - 2001. - Vol. 409, N 6822. - P. 860-921.

2. Eukaryotic transposable elements as mutagenic agent/ Eds Lambert M.E., McDonald J.F., Weinstein J.B. N.G.: Cold Spring Harbor Press, 1988. 345 p.

3. Георгиев П.Г. Роль мобильных элементов в мутагенезе, индуцированном химическими и физическими агентами: Автореф. дис. канд. биол. наук. М.: ИМБ AH CCCP, 1991. $24 \mathrm{c}$.

4. Kazazian H.H.J. Mobile elements and disease// Curr. Opin. Genet. Dev. - 1998. - Vol. 8, N 3. - P. 343-350.

5. Хесин Р.Б. Непостоянство генома. М.: Наука, 1984. 472 c.

6. Mobile DNA/ Eds Berg D.E., Howe M.M. Washington, D.C. (USA); Amer.Soc. Microbiol., 1989. 972p.

7. Ратнер В.А., Васильева Л.А. Мобильные генетические элементы (МГЭ): "эгоистическая ДНК” или функциональная часть генома?// Современные концепции эволюционной генетики/ Под ред. Шумного Б.К., Маркеля А.Л. Новосибирск ИциГ СЩ PAH , 2000, c. 128-150.

8. Shapiro J.A. Repetitive DNA, genome system architecture and genome reorganization// Res. Microbiol. - 2002. Vol. 153, N 7. - P. 447-453.

9. McClintock $B$. The significance of responses of the genome to challenge// Science. - 1984. -Vol. 226, N 4676. - P. 792-801.

10.Fedoroff N., Botstein D. The dynamic genome: Barbara McClintock's ideas in the century of genetics// Cold Spring Harbor, N.Y.: Cold Spring Harbor Laboratory Press, 1992. $422 \mathrm{p}$.

11. Capy P., Gasperi G., Biemont C., Bazin C. Stress and transposable elements: co-evolution or useful parasites?// Heredity. - 2000. - Vol. 85, N 2. P. 101-106.

12. Fedoroff N.V. Transposable elements as a molecular evolutionary force// Ann. NYAcad. Sci. - 2002. - Vol. 981. P. 154-188.

13. Britten R.J. DNA sequence insertion and evolutionary variation in gene regulation// Proc. Natl. Acad. Sci. USA. - 1996. - Vol. 93, N 18. - P. 9374-9377.

14.Kidwell M.G., Lisch D. Transposable elements as sources of variation in animals and plants// Proc.Natl. Acad. Sci. USA. - 1997. Vol. 94, N 15. - P. 7704-7711.

15. Jordan I.K., Rogozin I.B., Glasko G.V., Koomin E.V. Origin of a substantial fraction of human regulatory sequences from transposable elements// Trends Genet. - 2003. Vol. 19, N 2. - P. 68-72.
16. Britten R.J. Mobile elements inserted in the distant past have taken on important functions// Gene. - 1997. - Vol. 205, N 1-2. -P. 177-182.

17.Brosius J. RNAs from all categories generate retrosequences that may be exapted as novel genes or regulatory elements// Gene. - 1999. - Vol. 238, N 1. - P. 115-134.

18. van de Lagemaat L.N., Landry J.R., Mager D.L., Medstrand $P$. Transposable elements in mammals promote regulatory variation and diversification of genes with specialized functions// Trends Genet. - 2003. - Vol. 19, N 10. - 10. -P.530-536.

19. Nekrutenko A., Li $W-H$. Transposable elements are found in a large number of human protein-coding genes// Trends Genet. - 2001. - Vol. 17, N 11. - P.619-621.

20. Hon L.S., Jain A.N. Compositional structure of repetitive elements is quantitatively related to coexpression of gene pairs// J. Mol. Biol. - 2003. - Vol. 332, N 2. - P.305-310.

21. Hollstein M., Sidransky D., Vogelstein B., Harris C.C. P53 mutations in human cancer// Science. - 1991. - Vol. 253, N 5015. - P.49-53.

22. Levine A.J., Momand J., Finlay C.A. The p53 tumor suppressor gene// Nature. - 1991. - Vol. 351, N 6326. P.453-456.

23. Lane D.P. P53, guardian of the genome// Nature. - 1992. - Vol. 358, N 6381. - P.15-16.

24. Bargonetti J., Manfredi J.J. Multiple roles of the tumor suppressor p53// Curr. Opin. Oncol. - 2002. - Vol. 14, N 1. - P.86-91.

25. Fridman J.S., Lowe S.W. Control of apoptosis by p53// Oncogene. - 2003. - Vol. 22, N 56. - P.9030-9040.

26. Futreal P.A., Barrett J.C., Wiseman R.W. An Alu polymorphism intragenic to the TP53 gene// Nuclear Acids Res. 1991. - Vol. 19, N 24. - P.6977.

27. Fu L., Ma W., Benchimol S. A translation repressor element resides in the 3 ? untranslated region of human $\mathrm{p} 53$ mRNA// Oncogene.- 1999.-Vol.18, № 47. - P.6419-6424.

28. Шахмурадов И.А., Колчанов Н.А., Капитонов В.В. Распространение повторов Alu человека по геному: формирование кластеров и особенности участков встраивания// Мол. биол. - 1989. - Т. 23, вып. 2. C.526-536.

29. Pavlicek A., Jabbari K., Paces J., Paces V., HeJnar J.V., Bernardi $G$. Similar integration but different stability of Alus and LINEs in the human genome// Gene. - 2001. Vol. 276, N 1-2. -P.39-45.

30. Jurka J., Krujajic M., Kapitonov V.V., Stenger J.E., KoHany $O$. Active Alu elements are passed primarily through paternal germlines// Theor. Popul. Biol. - 2002. Vol. 61, N 4. - P.519-530.

31. Toda G., Tomita M. Alu elements as an aid in deciphering genome rearrangements// Gene. - 1997. - Vol. 205, N 1-2. P.173-176.

32. Kulski J.K., Gandierri S., Bellgard M., Balmer L., Giles K., Inoko H., Dawkins R.L. The evolution of MNC diversity by segmental duplication and transposition of retroelements// J. Mol. Evol. - 1997. - Vol. 45, N 6. - P. 599-609.

33.Jurka J., Kohany O., Pavlicek A., Kapitonov V.V., Jurka M.V. Duplication, coclustering, and selection of human Alu retrotransposones// PNAS. - 2004. - Vol. 101, N 5. - P. 1268-1272. 
34. Kolomietz E., Meyn M.S., Pandita A., Squire J.A. The role of Alu repeat cluster as mediators of recurrent chromosomal aberrations in tumors// Genes, Chromosomes, Cancer. - 2002. - Vol. 35, N 2. - P. 97-112.

35. Ory K., Legros Y., Auguin C., Soussi T. Analysis of the most representative tumor-derived p53 mutants reveals that changes in protein conformation are not correlated with loss of transactivation or inhibition of cell proliferation// EMBO J. - 1994. - Vol. 13, N 15. - P. 3496-3504.

36. Slebos R.S., Resnick M.A., Taylor J.A. Inactivation of the p53 tumor suppressor gene via a novel Alu rearrangement// Cancer Res.- 1998. - Vol. 58, N 23. - P. 5333-5336.

37. Bougeard G., Brugieres L., Chompret A., Gesta P., Charbonnier F., Valent A., Martin C., Raux G., Feunteun J., Paillerets B.B., Frebourg T. Screening for TP53 rearrangements in families with the Li-Fraumeni syndrome reveals a complete deletion of the TP53 gene// Oncogene. - 2003. Vol.22, N 6. - P. 840-846.
38. Ратнер В.А., Васильева Л.А. Роль мобильных генетических элементов (МГЭ) в микроэволюции// Генетика. - 1992. - Т.28, N 12. - С. 5-15.

39. Vansant G., Reynolds W.F. The consensus sequence of a major Alu subfamily contains a functional retinoic acid response element// Proc. Natl. Acad. Sci. USA. - 1995. Vol.92, N 18. - P. 8229-8233.

40. Babich V., Aksenov N., Alexeenko V., Oei S.L., Buchlow G., Tomilin $N$. Association of some potential hormone response elements in human genes with the Alu family repeats// Gene. - 1999. - Vol. 239, N 2. - P. 341-349.

УДК $575.113+577.2+599.89$

Надійшла до редакції 07.12.04 